\title{
1 Towards a global interpretation of dual 2 nitrate isotopes in surface waters
}

3 Venkiteswaran $\mathrm{JJ}^{1}$, Boeckx $\mathrm{P}^{2}$, Gooddy $\mathrm{DC}^{3}$

$4 \quad{ }^{1}$ Department of Geography and Environmental Studies, Wilfrid Laurier University, Waterloo,

5 Ontario, Canada, jvenkiteswaran@wlu.ca, orcid: 0000-0002-6574-7071

$6 \quad{ }^{2}$ Isotope Bioscience Laboratory - ISOFYS, Ghent University, Coupure Links 653, 9000 Gent,

7 Belgium, orcid: 0000-0003-3998-0010

$8{ }^{3}$ British Geological Survey, Maclean Building, Crowmarsh, Oxfordshire OX10 8BB, United

9 Kingdom, orcid: 0000-0002-6015-1332

10 Keywords: nitrate, isotopes, lakes, rivers 


\section{Abstract:}

Modern anthropogenic activities have significantly increased nitrate $\left(\mathrm{NO}_{3}{ }^{-}\right)$concentrations in surface waters. Stable isotopes $\left(\delta^{15} \mathrm{~N}\right.$ and $\left.\delta^{18} \mathrm{O}\right)$ in $\mathrm{NO}_{3}{ }^{-}$offer a tool to deconvolute some of the human-made changes in the nitrogen cycle. They are often graphically illustrated on a template designed to identify different sources of $\mathrm{NO}_{3}{ }^{-}$and denitrification. In the two decades since this template was developed, $\delta^{15} \mathrm{~N}$ - and $\delta^{18} \mathrm{O}_{-} \mathrm{NO}_{3}{ }^{-}$have been measured in a variety of ecosystems and through the nitrogen cycle. However, its interpretation is often fuzzy or complex. This default is no longer helpful because it does not describe surface water ecosystems well and biases researchers towards denitrification as the $\mathrm{NO}_{3}{ }^{-}$ removal pathway, even in well oxygenated systems where denitrification is likely to have little to no influence on the nitrogen cycle. We propose a different scheme to encourage a better understanding of the nitrogen cycle and interpretation of $\mathrm{NO}_{3}{ }^{-}$isotopes. We use a mechanistic understanding of $\mathrm{NO}_{3}{ }^{-}$ formation to place bounds on the oxygen isotope axis and provide a means to adjust for different environmental water isotope values, so data from multiple sites and times of year can be appropriately compared. We demonstrate that any interpretation of our example datasets (Canada, Kenya, United Kingdom) show clear evidence of denitrification or a mixture of $\mathrm{NO}_{3}{ }^{-}$sources simply because many data points fall outside of arbitrary boxes which cannot be supported once the range of potential $\delta^{18} \mathrm{O}-$ $\mathrm{NO}_{3}{ }^{-}$values has been considered.

\section{Highlights:}

- Interpretation of surface water $\delta^{15} \mathrm{~N}$ - and $\delta^{18} \mathrm{O}_{-} \mathrm{NO}_{3}{ }^{-}$requires a more complex framework than currently employed

- Surface water processes alter $\delta^{15} \mathrm{~N}$ - and $\delta^{18} \mathrm{O}-\mathrm{NO}_{3}{ }^{-}$in different ways than the traditional groundwater-denitrification model rendering such frameworks obsolete

- Mechanistic understanding of $\mathrm{NO}_{3}{ }^{-}$cycling in surface waters means that the range of $\delta^{18} \mathrm{O}$ $\mathrm{NO}_{3}{ }^{-}$is constrainable and can be made comparable between sites and across time via concurrent measurements of $\delta^{18} \mathrm{O}-\mathrm{H}_{2} \mathrm{O}$ and $\delta^{18} \mathrm{O}-\mathrm{O}_{2}$

\section{Introduction:}

37 Stable isotopes $\left(\delta^{15} \mathrm{~N}\right.$ and $\left.\delta^{18} \mathrm{O}\right)$ in nitrate $\left(\mathrm{NO}_{3}^{-}\right)$have been commonly measured for more than 4

38 decades (see Heaton (1986) and papers therein). Methods have evolved from off-line $\mathrm{AgNO}_{3}$

39 precipitation (e.g., Chang et al. 1999; Silva et al. 2000), to chemical and microbial reduction to $\mathrm{N}_{2} \mathrm{O}$

40 and subsequent continuous flow - isotope ratio mass spectrometry analyses (Sigman et al. 2001;

41 McIlvin and Altabet 2005). Since $\mathrm{NO}_{3}{ }^{-}$is a very common global pollutant, contributes to

42 eutrophication of surface waters (Vitousek et al. 1997) and is the most common groundwater pollutant

43 (Spalding and Exner 1993), a key application of $\mathrm{NO}_{3}{ }^{-}$isotopes was to identify $\mathrm{NO}_{3}{ }^{-}$sources. Through

44 combining a number of individual studies, this lead to publication of a $\delta^{18} \mathrm{O}_{-} \mathrm{NO}_{3}{ }^{-}$vs $\delta^{15} \mathrm{~N}_{-} \mathrm{NO}_{3}{ }^{-}$

45 schematic biplot with suggested ranges for different 'sources' of $\mathrm{NO}_{3}^{-}$(Kendall 1998). It has been

46 modified a few times (e.g., Kendall et al. 2008; Xue et al. 2009; Kendall et al. 2015) but the

47 fundamental concept remained the same. Its application for interpreting $\mathrm{NO}_{3}{ }^{-}$isotopes has become

48 widespread but this figure is not really fit for this purpose and is commonly over-interpreted. Here, we 
49 discuss the assumptions inherent in this figure and key improvements needed for improved

50 understanding of $\mathrm{NO}_{3}{ }^{-}$isotopes in surface waters.

\section{Background}

52 The schematic biplot figure was originally designed for interpreting groundwater data where $\mathrm{NO}_{3}{ }^{-}$

53 isotope values of different $\mathrm{NO}_{3}{ }^{-}$sources are preserved except by (chemo)denitrification (e.g., Böttcher

54 et al. 1990; Aravena et al. 1993; Aravena and Robertson 1998). Some researchers identified that

55 forests receiving a lot of nitrogen deposition export $\mathrm{NO}_{3}{ }^{-}$in streams and this $\mathrm{NO}_{3}{ }^{-}$does not retain the

56 atmospheric deposition isotope values (e.g., Spoelstra et al. 2001; Pardo et al. 2004). This was early

57 evidence that measured $\mathrm{NO}_{3}{ }^{-}$isotopes in surface water showed that they should be carefully used for

58 source identification because of various biological alterations along their flowpath. As method

59 improvements allowed more $\mathrm{NO}_{3}{ }^{-}$isotope data to be generated, a schematic figure that recognised

60 biotic and abiotic processing of $\mathrm{NO}_{3}{ }^{-}$between its sources and sampling point needed to be developed.

61 Knowledge of isotope fractionation during $\mathrm{NO}_{3}^{-}$production and consumption was summarised in

62 Kendall (1998) yet, despite the many figures in this chapter, one figure described as "simplified" has

63 become the ubiquitous interpretation scheme. This figure visually summarises a compilation of $\mathrm{NO}_{3}{ }^{-}$

64 isotope data with boxes by "dominant sources of nitrate" and encourages researchers to think only

65 about one process, denitrification, although this process may be uncommon in well oxygenated lake

66 surfaces or streams and rivers. In this way, we need a better schematic figure that explicitly recognises

67 the differences between $\mathrm{NO}_{3}{ }^{-}$sources and processes that produce and consume $\mathrm{NO}_{3}{ }^{-}$.

68 The "nitrogen axis" had been used as the primary differentiator between sources. However, given the

69 wide range of possible $\delta^{15} \mathrm{~N}$ values in manure/sewage and soils (e.g., 30\%o range in soil alone, Craine

70 et al. 2015), and the obvious fact that nitrogen will be biologically cycled in those systems, source

71 identification cannot be done with boxes on a figure. Moreover, a system with three $\mathrm{NO}_{3}{ }^{-}$sources and

72 only one measurement, $\delta^{15} \mathrm{~N}$, is underdetermined. Measuring locally appropriate sources of nitrogen

73 as potential initial $\delta^{15} \mathrm{~N}$ values is the appropriate way to constrain this axis instead of relying on the

74 broad assumption that a single set of boxes, derived from a limited number of measurements, are

75 globally appropriate (Bateman and Kelly 2007). Without locally appropriate values, the borders

76 between $\mathrm{NO}_{3}{ }^{-}$sources become very blurred on the $\delta^{15} \mathrm{~N}^{-\mathrm{NO}_{3}}{ }^{-}$axis (e.g., Kendall et al. 2015) and this

77 provides no useful resolution in the measured surface water data and no direct ability to identify

78 sources.

79 In some cases, nitrogen from fertilizers and legumes will be mixed into the soil nitrogen pool (e.g.,

80 Oelmann et al. 2007) before $\mathrm{NO}_{3}{ }^{-}$is exported to surface waters (e.g., Deutsch et al. 2006). In such

81 cases the exported $\delta^{15} \mathrm{~N}_{-} \mathrm{NO}_{3}{ }^{-}$values will be controlled largely by the soil nitrogen pool and land-use

82 history, rather than a single year of precipitation and fertilizer input (e.g., Loo et al. 2017). In this

83 scenario the soil nitrogen averages all of its nitrogen inputs and $\mathrm{NO}_{3}{ }^{-}$subsequently exported from the

84 soil to surface water maintains this average unless there is direct input of isotopically district $\mathrm{NO}_{3}{ }^{-}$to

85 the surface waters. Hence the large overlap in the $\mathrm{NO}_{3}{ }^{-}$sources boxes that does not contribute to

86 source identification (e.g., Kendall et al. 2015).

87 The "oxygen axis" has groups that can be defined a priori: (i) high $\delta^{18} \mathrm{O}$ values from $\mathrm{NO}_{3}$ - produced in 88 the atmosphere where the $\delta^{18} \mathrm{O}$ value depends strongly on latitude (Michalski et al. 2012); and (ii) low 
$\delta^{18} \mathrm{O}$ values where the $\delta^{18} \mathrm{O}$ value depends strongly on the $\delta^{18} \mathrm{O}$ of $\mathrm{H}_{2} \mathrm{O}$ where the $\mathrm{NO}_{3}{ }^{-}$is formed

90 (Snider et al. 2010). The $\delta^{18} \mathrm{O}$ value of $\mathrm{NO}_{3}{ }^{-}$produced by autotrophic and heterotrophic nitrification can be bounded in two ways. First, canonical two-step nitrification (from $\mathrm{NH}_{4}{ }^{+}$to $\mathrm{NH}_{2} \mathrm{OH}$ to $\mathrm{NO}_{2}{ }^{-}$to $\mathrm{NO}_{3}{ }^{-}$) adds one $\mathrm{O}$ atom from $\mathrm{O}_{2}$ in the first step and one $\mathrm{O}$ atom from $\mathrm{H}_{2} \mathrm{O}$ in each of the next two steps (Hollocher et al. 1981; Andersson et al. 1983; Aleem et al. 1965; Hollocher 1984; DiSpirito and Hooper 1986). Isotope fractionation during these steps occurs but is not always expressed, such as when $\mathrm{NO}_{2}{ }^{-}$is fully consumed (Buchwald and Casciotti 2010; Casciotti et al. 2010; Snider et al. 2010). Abiotic equilibrium of oxygen may occur between $\mathrm{H}_{2} \mathrm{O}$ and $\mathrm{NO}_{2}{ }^{-}$and increase the $\delta^{18} \mathrm{O}$ value of the $\mathrm{NO}_{2}^{-}$(Casciotti et al. 2007). In surface soils, the pore gas $\delta^{18} \mathrm{O}-\mathrm{O}_{2}$ value is very likely near the atmospheric value of $+23.5 \%$ (vs SMOW; Kroopnick and Craig 1972). However, in productive aquatic ecosystems, the diel variability of $\delta^{18} \mathrm{O}-\mathrm{O}_{2}$ values can be large (e.g., 26\% range in Gammons et al. 2011, 23\%o range in Venkiteswaran et al. 2015, 18\%o range in Hotchkiss and Hall, Jr 2014, 14\%o range in Wassenaar et al. 2010, and 13\%o range in Parker et al. 2005) though this range can be estimated by one set of diel samples during the most productive part of the year and analyzed via a variety of techniques (e.g., Barth et al. 2004; Wassenaar and Koehler 1999). Second, incubation experiments with various levels of $\delta^{18} \mathrm{O}-\mathrm{H}_{2} \mathrm{O}$ indicate that the contribution of $\delta^{18} \mathrm{O}-\mathrm{H}_{2} \mathrm{O}$ values to the final $\delta^{18}{\mathrm{O}-\mathrm{NO}_{3}}^{-}$value is often much greater than the minimum two-thirds and sometimes close to 1 (Snider et al. 2010). Thus the range of $\delta^{18} \mathrm{O}$ values of $\mathrm{NO}_{3}{ }^{-}$produced in situ can be bounded by knowledge of $\delta^{18} \mathrm{O}-\mathrm{O}_{2}$ and $\delta^{18} \mathrm{O}-\mathrm{H}_{2} \mathrm{O}$ values: a minimum of the $\delta^{18} \mathrm{O}-\mathrm{H}_{2} \mathrm{O}$ value and a maximum of $1 / 3$ $\times \delta^{18} \mathrm{O}-\mathrm{O}_{2}+2 / 3 \times \delta^{18} \mathrm{O}-\mathrm{H}_{2} \mathrm{O}$. However, abiotic exchange of oxygen between $\mathrm{H}_{2} \mathrm{O}$ and $\mathrm{NO}_{2}^{-}$may increase this theoretical minimum value. When the diel range in $\delta^{18} \mathrm{O}_{-} \mathrm{O}_{2}$ values is considered the maximum $\delta^{18} \mathrm{O}$ values of $\mathrm{NO}_{3}^{-}$produced in situ will vary by upwards of $10 \%$ (i.e., $1 / 3$ of the diel range of $\delta^{18} \mathrm{O}-\mathrm{O}_{2}$ values, e.g., 9\%o in Gammons et al. 2011, 8\%o in Venkiteswaran et al. 2015, 6\%o in Hotchkiss and Hall, Jr 2014, 5\%o in Wassenaar et al. 2010, and 4\%o range in Parker et al. 2005). Data in Silver Bow Creek, Montana, USA exhibit synchronous diel $\delta^{18} \mathrm{O}-\mathrm{NO}_{3}{ }^{-}$and $\delta^{18} \mathrm{O}-\mathrm{O}_{2}$ cycles (Gammons et al. 2011).

\section{Site descriptions:}

116 To highlight the need to include nitrogen cycling in surface waters into our working interpretation of $117 \mathrm{NO}_{3}{ }^{-}$isotopes, we selected six rivers from Canada, Kenya, and the United Kingdom each with different climate regions, seasonal variation in flow, and $\delta^{18} \mathrm{O}-\mathrm{H}_{2} \mathrm{O}$ values.

The Grand River, Ontario, Canada is the largest river draining into the Canadian side of Lake Erie. There are five cities, 30 wastewater treatment plants, and extensive modern agriculture along the $300 \mathrm{~km}$ river in its $6800 \mathrm{~km}^{2}$ basin (Venkiteswaran et al. 2015). Climate is humid continental with a warm summer (Köppen-Geiger classification Dfb), average temperature is around $9{ }^{\circ} \mathrm{C}$ and mean precipitation is $915 \mathrm{~mm}$. Samples were collected weekly to monthly from March 2015 to March 2016 from three sites: two sites upstream of the first major city and first large wastewater treatment plant and one below two cities and two large wastewater treatment plants. These sites offer the opportunity to sample from the river largely affected by diffuse non-point sources and after two large point sources (Hood et al. 2014; Venkiteswaran et al. 2018). All sites are in the middle of the Grand River and were sampled at baseflow. 
drainage comprises $40 \%$ of the inflows to Lake Victoria (COWI 2002) and is therefore a significant source of the increasing nutrient concentrations in the lake (Juma et al. 2014). Eight sites on the Nzoia River, 11 sites on the Nyando River, and five sites in the Sondu River were sampled from January to April 2015. Sampling sites were selected based on access to the river and upstream land use. Climate in western Kenya is tropical rainforest and tropical monsoon (Köppen-Geiger classifications Af and Am).

The UK study sites compare nitrogen sources from peri-urban and rural river floodplains. Climate is maritime (Köppen-Geiger classification $\mathrm{Cfb}$ ). Site 1 focuses on a peri-urban section of the River Thames in the vicinity of the city of Oxford in the southern UK. The mean annual flow of the Thames upstream of the study area is $18.48 \mathrm{~m}^{3} / \mathrm{s}$ (Marsh and Hannaford, 2008). The baseflow index for the river at this location is 0.67 , reflecting the influence of influent groundwater, sourced from the limestone aquifers located in the headwaters, and the extensive floodplain gravel aquifers. During the summer a significant component of flow is supported by effluent from Wastewater Treatment Works (WwTW) (Bowes et al., 2010). Five sites upstream and downstream of a WwTW were selected along the Thames and sampled in April and September 2016 for $\mathrm{NO}_{3}{ }^{-}$isotopes at steady-state flow. Site 2 is on the River Lambourn in Berkshire. Chalk streams such as this are widespread across southern England (Allen et al., 2010). They are characterised by a high baseflow index $(>0.9)$ and a shallow hyporheic zone. The primary source of nitrogen therefore comes from $\mathrm{NO}_{3}{ }^{-}$in groundwater due to fertilizer use. Samples were collected at steady-state flow.

\section{Methods:}

Canadian samples for $\mathrm{NO}_{3}{ }^{-}$isotopes were collected in HDPE bottles and filtered in the field to $0.45 \mu \mathrm{m}$. Samples were kept cold and dark until returned to the lab where they were frozen until analysed. Samples for $\mathrm{H}_{2} \mathrm{O}$ isotopes were collected in HDPE bottles without headspace. Canadian analyses were performed at the Environmental Isotope Laboratory at the University of Waterloo. $\mathrm{NO}_{3}{ }^{-}$ isotope samples were analysed via the chemical denitrifier method where $\mathrm{NO}_{3}{ }^{-}$is reduced to $\mathrm{N}_{2} \mathrm{O}$ with cadmium and sodium azide (McIlvin and Altabet 2005). The resultant $\mathrm{N}_{2} \mathrm{O}$ gas was analysed on an IsoPrime continuous flow isotope ratio mass spectrometer (now Elementar, Cheadle Hulme, UK) with a precision of $\pm 0.3 \%$ for $\delta^{15} \mathrm{~N}-\mathrm{NO}_{3}{ }^{-}$and $\pm 0.5 \%$ for $\delta^{18} \mathrm{O}_{-}-\mathrm{NO}_{3}{ }^{-}$. Water isotopes were measured on a a Los Gatos (Los Gatos Research, San Jose, USA) water isotope analyser with a precision of $\pm 0.2 \%$ for $\delta^{18} \mathrm{O}-\mathrm{H}_{2} \mathrm{O}$.

Kenyan samples were filtered to $0.45 \mu \mathrm{m}$ and stored below $4^{\circ} \mathrm{C}$ in $1 \mathrm{~L}$ HDPE bottles. Kenyan analyses were performed at the Ghent University Stable Isotope Facility (UGent-SIF). $\mathrm{NO}_{3}{ }^{-}$isotopes were analysed by the bacterial denitrification method (Xue et al., 2009) and the resulting $\mathrm{N}_{2} \mathrm{O}$ gas analyzed with a SerCon trace gas preparation unit coupled to a SerCon 20-20 isotope ratio mass spectrometer (SerCon, Crewe, UK).

UK samples were also filtered to $0.45 \mu \mathrm{m}$ and stored below $4^{\circ} \mathrm{C}$ in $1 \mathrm{~L}$ HDPE bottles. Isotope preparation and analysis for UK samples was carried out at the NERC Isotope Geosciences Laboratory (Keyworth, UK). $\mathrm{NO}_{3}{ }^{-}$was separated on anion resins and prepared as $\mathrm{AgNO}_{3}$ using the method of Silva et al. (2000) and $\delta^{15} \mathrm{~N}$ analysed by combustion in a Flash EA coupled to a Delta Plus XL mass spectrometer (ThermoFinnigan, Bremen, Germany) with precision (1 SD) typically $<0.8 \%$. $\delta^{18} \mathrm{O}$ was analysed by thermal conversion to $\mathrm{CO}$ gas at $1400^{\circ} \mathrm{C}$ in a TC-EA online to a Delta Plus XL 
mass spectrometer with precision $(1 \mathrm{SD})$ typically $<1.2 \%$.

\section{Results and Discussion:}

173 On the traditional biplot, our data from Canada, Kenya, and the United Kingdom fall in a wide swath

174 (Figure 1A). Data from each country has a wider range of $\delta^{15} \mathrm{~N}_{-} \mathrm{NO}_{3}{ }^{-}$values than $\delta^{18} \mathrm{O}^{-} \mathrm{NO}_{3}{ }^{-}$values

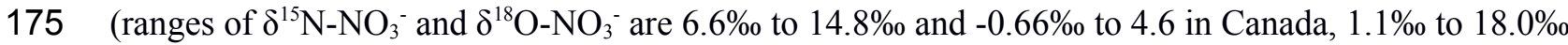
176 and $2.1 \%$ to $19.7 \%$ in Kenya, and $3.4 \%$ o to $17.2 \%$ and $-0.95 \%$ to $9.9 \%_{0}$ in the United Kingdom).

177 Additionally, data from each country has a positive relationship between $\delta^{18} \mathrm{O}-\mathrm{NO}_{3}{ }^{-}$and $\delta^{15} \mathrm{~N}_{-} \mathrm{NO}_{3}{ }^{-}(2-$

178 tailed parametric $p<0.006$ for each country). But this relationship also contains seasonal changes in

179 ambient $\delta^{18} \mathrm{O}-\mathrm{H}_{2} \mathrm{O}$ values, temperature, and nitrogen sources and processes that confound direct

180 comparison of the data.

181 This means that without additional independent information, there are several possible explanations for the data that are more complex than simply assigning a source of $\mathrm{NO}_{3}{ }^{-}$based on the $\delta^{15} \mathrm{~N}$ values or

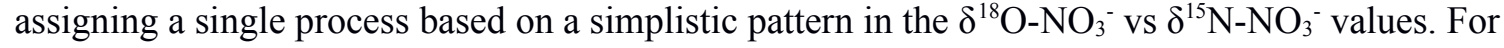
example, varying contributions of the $\delta^{18} \mathrm{O}-\mathrm{H}_{2} \mathrm{O}$ values, two or more sources of nitrogen, uptake and release of varying amounts of ammonium and $\mathrm{NO}_{3}{ }^{-}$, and denitrification in varying combinations may have produced the observed patterns in our data. It is critical to avoid wrongly invoking denitrification as the primary explanation for individual points on the traditional biplot as this risks suggesting nitrogen removal from the ecosystem when other explanations for the data need to be considered.

Certainly, any interpretation that our data show clear evidence of denitrification or a mixture of $\mathrm{NO}_{3}{ }^{-}$ sources because many data points fall outside of arbitrary boxes with the traditional $\delta^{18} \mathrm{O}$ axis (Fig. 1A) cannot be supported once the range of potential $\delta^{18} \mathrm{O}_{-} \mathrm{NO}_{3}{ }^{-}$values has been considered (Fig. 1B). Moreover, almost all measured $\delta^{18} \mathrm{O}-\mathrm{NO}_{3}{ }^{-}$values fall within the range of expected $\delta^{18} \mathrm{O}-\mathrm{NO}_{3}{ }^{-}$values based on nitrification with variable amount of $\mathrm{H}_{2} \mathrm{O}$ exchange (Fig. 1B). Thus, the theoretical range of

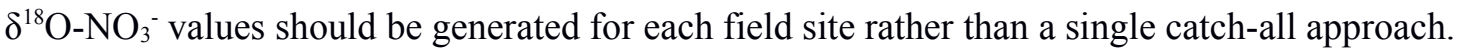
Globally, $\delta^{18} \mathrm{O}-\mathrm{H}_{2} \mathrm{O}$ values of surface water vary widely along a meteoric water line, but they can be predicted by latitude and databases such as waterisotopes.org though direct measurement is much simpler than $\mathrm{NO}_{3}{ }^{-}$isotopes. Additionally, to make $\delta^{18} \mathrm{O}_{-}-\mathrm{NO}_{3}{ }^{-}$data comparable between seasons and sites, $\delta^{18} \mathrm{O}-\mathrm{NO}_{3}{ }^{-}$data should be displayed vs the $\delta^{18} \mathrm{O}-\mathrm{H}_{2} \mathrm{O}$ value from the same sample (i.e., same location and time) rather than vs SMOW ${ }^{1}$. This is the ${ }^{18} \mathrm{O} /{ }^{16} \mathrm{O}$ ratio of $\mathrm{NO}_{3}{ }^{-}$divided by the ${ }^{18} \mathrm{O} /{ }^{16} \mathrm{O}$ ratio of $\mathrm{H}_{2} \mathrm{O}$ rather than by the ${ }^{18} \mathrm{O} /{ }^{16} \mathrm{O}$ ratio of SMOW. This is akin to the way $\delta^{18} \mathrm{O}_{-} \mathrm{PO}_{4}{ }^{3-}$ values are plotted relative to their temperature-specific equilibrium point with $\delta^{18} \mathrm{O}-\mathrm{H}_{2} \mathrm{O}$ (e.g., Davies et al. 2014, Paytan et al. 2002) in order to remove the influence of difference $\delta^{18} \mathrm{O}-\mathrm{H}_{2} \mathrm{O}$ values (Figure 1B). Here the differences in $\delta^{18} \mathrm{O}-\mathrm{NO}_{3}{ }^{-}$values between countries is much reduced and most $\delta^{18} \mathrm{O}-\mathrm{NO}_{3}{ }^{-}$values are near the upper-end of the $\delta^{18} \mathrm{O}-\mathrm{NO}_{3}{ }^{-}$values predicted from microbial transformation of nitrogen. There is a positive linear relationship between $\delta^{18} \mathrm{O}-\mathrm{NO}_{3}{ }^{-}$and $\delta^{15} \mathrm{~N}^{-N^{-}}{ }_{3}^{-}$in the Kenya and UK data $\left(p<10^{-4}\right)$ but not Canada $(p>0.4)$.

207 Some variability due to watershed size and seasonality can also be considered with this approach.

1 Unitless $\delta$ values are converted from 'relative to SMOW' to 'relative to $\mathrm{H}_{2} \mathrm{O}$ ' as:

$$
\delta^{18} \mathrm{O}-\mathrm{NO}_{3 \mathrm{H}_{2} \mathrm{O}}^{-}=\frac{\delta^{18} \mathrm{O}-\mathrm{NO}_{3 \text { SMOW }}^{-}+1}{\delta^{18} \mathrm{O}-\mathrm{H}_{2} \mathrm{O}_{\text {SMOW }}+1}-1
$$


First, as watershed size increases above a river sampling point the average duration the nitrogen spends in the watershed increases and thus the likelihood that the sampled $\mathrm{NO}_{3}{ }^{-}$had been assimilated and released multiple times approaches $100 \%$. Second, initial $\delta^{18} \mathrm{O}_{-} \mathrm{NO}_{3}{ }^{-}$values entirely depend on the ambient $\delta^{18} \mathrm{O}-\mathrm{H}_{2} \mathrm{O}$ and $\delta^{18} \mathrm{O}-\mathrm{O}_{2}$ at the time of nitrification and not the $\delta^{18} \mathrm{O}$ value of the $\mathrm{NO}_{3}{ }^{-}$added to the watershed at some point upstream if the nitrogen has been cycled at least once. Thus changes in $\delta^{18} \mathrm{O}-\mathrm{H}_{2} \mathrm{O}$ between seasons or throughout watersheds (e.g., Yue et al. 2018) are accounted for by reporting $\delta^{18} \mathrm{O}_{-} \mathrm{NO}_{3}{ }^{-}$relative to the $\mathrm{H}_{2} \mathrm{O}$.

We recognise that in our approach that the $\delta^{18} \mathrm{O}-\mathrm{H}_{2} \mathrm{O}$ measured concomitantly with the $\delta^{18} \mathrm{O}-\mathrm{NO}_{3}{ }^{-}$does not completely represent the $\mathrm{H}_{2} \mathrm{O}$ that relevant during the most recent production of each $\mathrm{NO}_{3}{ }^{-}$ molecule. Indeed, the $\delta^{18} \mathrm{O}-\mathrm{H}_{2} \mathrm{O}$ during $\mathrm{NO}_{3}{ }^{-}$formation is not necessarily that which is found in the river during sampling due to mixing of a plethora of sources of $\mathrm{N}$ and $\mathrm{H}_{2} \mathrm{O}$. Similarly, small or slow flowing rivers maybe subject to significant seasonal evaporation resulting in increases in ambient $\delta^{18} \mathrm{O}-\mathrm{H}_{2} \mathrm{O}$ values that may temporally differ from when $\mathrm{NO}_{3}{ }^{-}$was formed. These issues reinforce the need to collect samples of waters where $\mathrm{NO}_{3}{ }^{-}$is formed, to recognise that $\mathrm{NO}_{3}{ }^{-}$is continuously cycled in surface waters, and to explicitly make a distinction between $\mathrm{N}$ sources and processing. The implication here is that identifying the source of the $\mathrm{NO}_{3}{ }^{-}$cannot be done with $\delta^{18} \mathrm{O}_{-} \mathrm{NO}_{3}{ }^{-}$values.

Increases in $\delta 15 \mathrm{~N}$ - and $\delta 18 \mathrm{O}-\mathrm{NO} 3$ - values, which are often interpreted as evidence of denitrification with closed-system assumptions (e.g., Böttcher et al. 1990), cannot be uniquely separated from multiple processes that recycle nitrogen in surface waters. Necessarily, this requires us to move beyond looking only for denitrification in our $\delta^{15} \mathrm{~N}$ - and $\delta^{18} \mathrm{O}-\mathrm{NO}_{3}{ }^{-}$data and towards how multiple processes and sources interact to produce the values measured in surface waters. Likely, this will ultimately require development of process-based $\mathrm{NO}_{3}{ }^{-}$isotope models for surface waters and will be informed by measurements of other nitrogen species, transformation processes and associated isotope enrichment factors (e.g., Venkiteswaran et al. 2018).

Only once the appropriate range of initial $\delta^{18} \mathrm{O}_{-} \mathrm{NO}_{3}{ }^{-}$values has been determined, can processes such as nitrification, denitrification, and $\mathrm{NO}_{3}{ }^{-}$assimilation be considered. Here, the $\delta^{15} \mathrm{~N}$ - and $\delta^{18} \mathrm{O}_{-} \mathrm{NO}_{3}{ }^{-}$ values in the environment will be pulled in multiple directions at the same time. The magnitude of change depends on multiple factors that are difficult or impossible to statically display in a biplot: (1) mineralization of organic nitrogen and subsequent nitrification may decrease $\delta^{15} \mathrm{~N}$ - and $\delta^{18} \mathrm{O}_{-} \mathrm{NO}_{3}{ }^{-}$ values depending on if there is a difference between the $\delta^{15} \mathrm{~N}$ value of organic nitrogen and $\mathrm{NO}_{3}{ }^{-}$and the $\delta^{18} \mathrm{O}$ contributions of $\mathrm{O}_{2}$ and $\mathrm{H}_{2} \mathrm{O}$; (2) ammonia and $\mathrm{NO}_{3}{ }^{-}$uptake and release by riverine periphyton and macrophytes may have differing impacts since isotope fractionation during ammonia uptake is non-linearly dependant on concentration (Fogel and Cifuentes 1993; Hoch et al. 1992) and denitrification in riparian zones and anoxic river and lake sediments may increase $\delta^{15} \mathrm{~N}$ - and $\delta^{18} \mathrm{O}_{-} \mathrm{NO}_{3}{ }^{-}$ values if there is residual $\mathrm{NO}_{3}{ }^{-}$to measure. In all cases, changes in the $\delta^{15} \mathrm{~N}$ - and $\delta^{18} \mathrm{O}-\mathrm{NO}_{3}{ }^{-}$values are more complex than a single arrow for denitrification suggests (Kendall 1998). A recent review has summarised the modelling approaches and isotope fractionation factors necessary to interpret measured $\delta^{15} \mathrm{~N}$ - and $\delta^{18} \mathrm{O}_{-} \mathrm{NO}_{3}{ }^{-}$values in soils (Denk et al. 2017). With this process-based understanding it is clear that a single vector or slope on a biplot for denitrification is inappropriate for surface waters. 


\section{Summary and Conclusions:}

249 In order to move beyond the simple source apportionment assumptions commonly made in $\mathrm{NO}_{3}{ }^{-}$

250 isotope biplots and to explicitly acknowledge that there are a variety of processes that alter the $\delta^{15} \mathrm{~N}$ 251 and $\delta^{18} \mathrm{O}-\mathrm{NO}_{3}{ }^{-}$values in situ we therefore recommend:

- Measuring $\delta^{18} \mathrm{O}-\mathrm{H}_{2} \mathrm{O}$ values at the same time as $\delta^{18} \mathrm{O}_{-} \mathrm{NO}_{3}{ }^{-}$values and report $\delta^{18} \mathrm{O}-\mathrm{NO}_{3}{ }^{-}$values vs $\delta^{18} \mathrm{O}-\mathrm{H}_{2} \mathrm{O}$ instead of $\mathrm{V}$-SMOW to make appropriate comparisons with time and across sites;

- Combining $\delta^{18} \mathrm{O}-\mathrm{H}_{2} \mathrm{O}$ and $\delta^{18} \mathrm{O}-\mathrm{O}_{2}$ values to develop appropriate site-specific ranges of $\delta^{18} \mathrm{O}$ $\mathrm{NO}_{3}{ }^{-}$produced in situ; and

- Measuring locally relevant $\delta^{15} \mathrm{~N}$ source values to significantly reduce the range of $\delta^{15} \mathrm{~N}$ values of nitrogen input to aquatic systems.

\section{Acknowledgements}

260 This work was completed under the auspices of the International Atomic Energy Agency's

261 Coordinated Research project 'Isotopes to Study Nitrogen Pollution and Eutrophication of Rivers and

262 Lakes' (F32007). Samples in Canada were collected under the Natural Science and Engineering

263 Research Council (NSERC) grant number STPGP-447692-2013. Samples in the UK were funded by

264 the Natural Environment Research Council (NERC) National Capability resources devolved to the

265 British Geological Survey. DCG publishes with permission of the Executive Director, British

266 Geological Survey (NERC). We thank the anonymous reviewers for their critical and supportive

267 comments. 


\section{Figure}
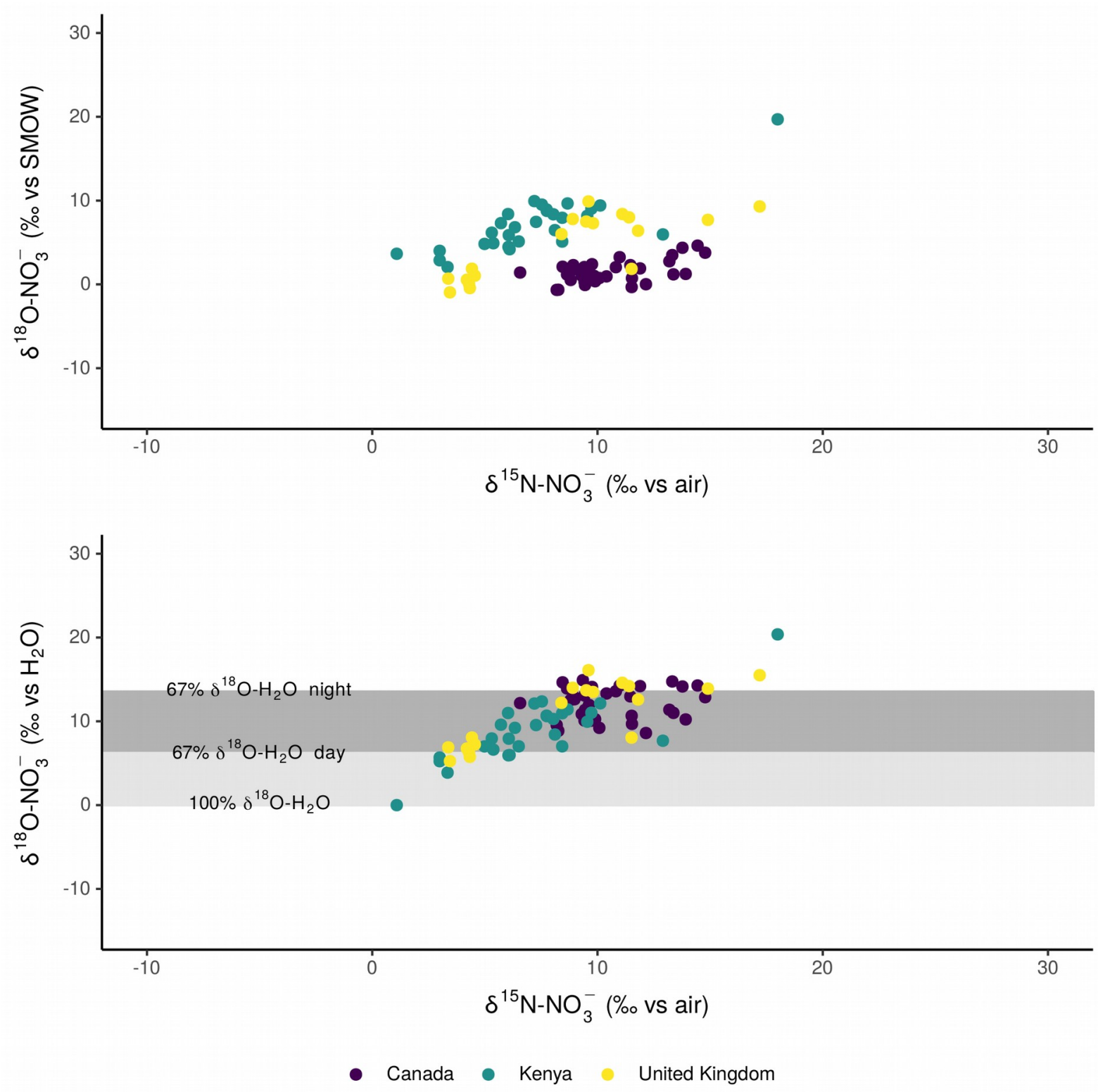

269 Figure 1 (a): Nitrate isotope biplot of data from three sites in the middle of the Grand River, Ontario,

270 Canada; 11 sites in the Nyando River, Kenya; eight sites in the Nzoia River, Kenya; five sites in the

271 Sondu River, Kenya; eight sites in the River Lambourn near Boxford, United Kingdom; and 11 sites

272 in the River Thames near Oxford, United Kingdom. Comparisons are difficult between seasons at one

273 site and still more difficult between sites because of the variability in $\delta^{18} \mathrm{O}-\mathrm{H}_{2} \mathrm{O}$ since the $\delta^{18} \mathrm{O}-\mathrm{NO}_{3}{ }^{-}$

274 axis is reported relative to the typical standard SMOW.

275 (b): Nitrate isotope biplot of the same data where the $\delta^{18} \mathrm{O}_{-}-\mathrm{NO}_{3}{ }^{-}$axis is reported relative to the ambient

$276 \delta^{18} \mathrm{O}-\mathrm{H}_{2} \mathrm{O}$ values in the river at the time of sampling, as per recommendation $\mathrm{A}$. The grey bands

277 indicates $\mathrm{NO}_{3}{ }^{-}$produced with a range of $\delta^{18} \mathrm{O}-\mathrm{NO}_{3}{ }^{-}$values based on a mixture of $\delta^{18} \mathrm{O}-\mathrm{O}_{2}$ and $\delta^{18} \mathrm{O}-$

$278 \mathrm{H}_{2} \mathrm{O}$ values. The minimum value is where the $\delta^{18} \mathrm{O}-\mathrm{H}_{2} \mathrm{O}$ is entirely retained in the $\delta^{18} \mathrm{O}-\mathrm{NO}_{3}{ }^{-}$value and

279 without isotope fractionation associated with abiotic oxygen exchange (Casciotti et al. 2007). The 
light grey band covers the range expected when $\delta^{18} \mathrm{O}-\mathrm{O}_{2}$ values are lowest during the day. The dark grey band extends the range expected when $\delta^{18} \mathrm{O}-\mathrm{O}_{2}$ values are greatest during the night (Venkiteswaran et al. 2015). Thus the $\delta^{18} \mathrm{O}$ value of newly producted $\mathrm{NO}_{3}{ }^{-}$in these rivers may cycle through these ranges on a diel basis. Here, data are more clearly expressed relative to the appropriate environmental conditions that recognise that nitrogen is biologically cycled and will be largely imprinted with the ambient $\delta^{18} \mathrm{O}-\mathrm{H}_{2} \mathrm{O}$ value with a minor contribution from the variable $\delta^{18} \mathrm{O}-\mathrm{O}_{2}$ value. A parsimonious interpretation here is that many data from Kenya and the UK exhibit the range of known contributions of the $\delta^{18} \mathrm{O}-\mathrm{H}_{2} \mathrm{O}$ values, i.e., from two-thirds to one. Most Canadian and some

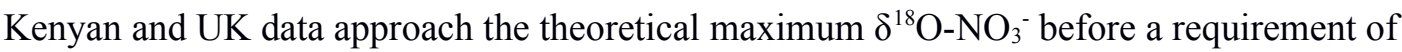
denitrification must be considered.

\section{References}

Aleem MIH, Hoch GE, Varner JE. 1965. Water as the source of oxidant and reductant in bacterial chemosynthesis. Biochemistry, 54, 869-873, DOI: 10.1073/pnas.54.3.869

Allen DJ, Darling WG, Gooddy DC, Lapworth DJ, Newell AJ, Williams AT, Allen D, Abesser C. 2010. Interaction between groundwater, the hyporheic zone and a Chalk stream: a case study from the River Lambourn, UK. Hydrogeology Journal 18(5): 1125-1141, DOI: 10.1007/s10040-010-0592-2

Andersson KK, Hooper AB. 1983. $\mathrm{O}_{2}$ and $\mathrm{H}_{2} \mathrm{O}$ are each the source of one $\mathrm{O}$ in $\mathrm{NO}_{2}{ }^{-}$produced from $\mathrm{NH}_{3}$ by Nitrosomonas: ${ }^{15} \mathrm{~N}-\mathrm{NMR}$ evidence. FEBS Lett. 164, 236-240, DOI: 10.1016/00145793(83)80292-0 Identification of Nitrate from Septic Systems. Groundwater, 31: 180-186, DOI: 10.1111/j.17456584.1993.tb01809.x

Aravena R. Robertson WD. 1998. Use of Multiple Isotope Tracers to Evaluate Denitrification in Ground Water: Study of Nitrate from a Large-Flux Septic System Plume. Groundwater, 36: 975-982, DOI: $10.1111 / \mathrm{j} .1745-6584.1998 . t b 02104 . x$

Bateman AS, Kelly SD. 2007. Fertilizer nitrogen isotope signatures, Isotopes in Environmental and

314 Barth JAC, Tait A, Bolshaw M (2004) Automated analyses of ${ }^{18} \mathrm{O} /{ }^{16} \mathrm{O}$ ratios in dissolved oxygen from 12-mL water samples. Limnol Oceanogr Meth 2:35-41, DOI: 10.4319/lom.2004.2.35

316 Böttcher J, Strebel O, Voerkelius S, Schmidt H-L. 1990. Using isotope fractionation of nitratenitrogen and nitrate-oxygen for evaluation of microbial denitrification in a sandy aquifer, Journal of Hydrology, 114, 413-424, DOI: 10.1016/0022-1694(90)90068-9 British rivers resulting from the introduction of improved phosphorus removal from sewage effluent. Science of The Total Environment 408(19): 4239-4250, DOI: 10.1016/j.scitotenv.2010.05.016.

322 Buchwald C, Casciotti KL. 2010. Oxygen isotopic fractionation and exchange during bacterial nitrite oxidation Limnol. Oceanogr. 55, 1064- 1074, DOI: 10.4319/lo.2010.55.3.1064 
324 Casciotti KL, Böhlke JK, McIlvin MR, Mroczkowski SJ, Hannon JE. 2007. Oxygen Isotopes in

325 Nitrite: Analysis, Calibration, and Equilibration. Anal. Chem. 79(6), 2427-2436, DOI:

326 10.1021/ac061598h

327 Casciotti KL, McIlvin M, Buchwald C. 2010. Oxygen isotopic exchange and fractionation during

328 bacterial ammonia oxidation. Limnol. Oceanogr. 55(2), 753-762, DOI: 10.4319/lo.2010.55.2.0753

329 Chang CCY, Langston J, Riggs M, Campbell DH, Silva SR, Kendall C. 1999. A method for nitrate

330 collection for $\delta^{15} \mathrm{~N}$ and $\delta^{18} \mathrm{O}$ analysis from waters with low nitrate concentrations. Can. J. Fish.

331 Aquatic Sci., 56, 1856-1864, DOI: 10.1139/f99-126

332 COWI Consulting Engineers, 2002. Integrated water quality/Limnology study for Lake Victoria. Lake

333 Victoria Environmental Management Project, Part II Technical Report.

334 Craine JM, Elmore AJ, Wang L, Augusto L, Baisden WT, Brookshire EN, Cramer MD, Hasselquist

335 NJ, Hobbie EA, Kahmen A, Koba K (2015) Convergence of soil nitrogen isotopes across global

336 climate gradients. Scientific Reports 5:8280, DOI: 10.1038/srep08280

337 Davies CL, Surridge DWJ, Gooddy DC (2014) Phosphate oxygen isotopes within aquatic ecosystems:

338 Global data synthesis and future research priorities. Sci Total Environ 496:563-575, DOI:

339 10.1016/j.scitotenv.2014.07.057

340 Denk TRA, Mohn J, Decock C, Lewicka-Szczebak D, Harris W, Butterbach-Bahl K, Kiese R, Wolf

341 B. 2017. The nitrogen cycle: A review of isotope effects and isotope modeling approaches. Soil

342 Biology and Biochemistry. 105, 121-137, DOI: 10.1016/j.soilbio.2016.11.015.

343 Deutsch B, Mewes M, Liskow I, Voss M. 2006. Quantification of diffuse nitrate inputs into a small

344 river system using stable isotopes of oxygen and nitrogen in nitrate. Organic Geochemistry, 37(10):

345 1333-1342, DOI: 10.1016/j.orggeochem.2006.04.012.

346 DiSpirito AA, Hooper AB. 1986. Oxygen exchange between nitrate molecules during nitrite oxidation

347 by Nitrobacter. J. Biol. Chem. 1986, 261, 10534-10537.

348 Fogel M L, Cifuentes LA. 1993. Isotope Fractionation during Primary Production. In Organic

349 geochemistry; Engel, H. M., Macko, S. A., Eds.; Plenum Press: New York; pp 73-98.

350 Gammons CH, Babcock JN, Parker SR, Poulson SR. 2011. Diel cycling and stable isotopes of

351 dissolved oxygen, dissolved inorganic carbon, and nitrogenous species in a stream receiving treated

352 municipal sewage. Chem. Geol. 283(102), 44-55, DOI: 10.1016/j.chemgeo.2010.07.006

353 Hannaford J, Marsh TJ. 2008. High-flow and flood trends in a network of undisturbed catchments in

354 the UK. International Journal of Climatology 28(10): 1325-1338, DOI: 10.1002/joc.1643

355 Heaton THE. 1986. Isotopic studies of nitrogen pollution in the hydrosphere and atmosphere: A

356 review. Chem Geol 59:87-102, DOI: 10.1016/0168-9622(86)90059-X

357 Hoch MP, Fogel ML, Kirchman DL. 1992. Isotope Fractionation Associated with Ammonium Uptake

358 by a Marine Bacterium. Limnol. Oceanogr., 37(7), 1447-1459, DOI: 10.4319/lo.1992.37.7.1447

EarthArXiv preprint DOI: 10.17605/OSF.IO/CZT8P 
Hollocher TC. 1984. Source of the oxygen atoms of nitrate in the oxidation of nitrite by Nitrobacter agilis and evidence against a P-O-N anhydride mechanism in oxidative phosphorylation. Arch. Biochem. Biophys. 233, 721-727, DOI: 10.1016/0003-9861(84)90499-5

Hollocher TC, Tate ME, Nicholas DJD. 1981. Oxidation of ammonia by Nitrosomonas europaea. J. Biol. Chem. 256, 10834-10836.

Hood JLA, Taylor WD, Schiff SL. 2014. Examining the fate of WWTP effluent nitrogen using $\delta^{15} \mathrm{~N}-$ $\mathrm{NH}_{4}{ }^{+}, \delta^{15} \mathrm{~N}-\mathrm{NO}_{3}{ }^{-}$and $\delta^{15} \mathrm{~N}$ of submersed macrophytes. Aquat. Sci. 76(2), 243-258, DOI: $10.1007 / \mathrm{s} 00027-013-0333-4$

Hotchkiss ER. Hall Jr, RO. 2014. High rates of daytime respiration in three streams: Use of $\delta^{18} \mathrm{O}_{\mathrm{O} 2}$ and $\mathrm{O}_{2}$ to model diel ecosystem metabolism. Limnol. Oceanogr. 59(3), 798-810, DOI: $10.4319 / 10.2014 .59 .3 .0798$

Juma DW, Wang H, Li F. 2014. Impacts of population growth and economic development on water quality of a lake: case study of Lake Victoria Kenya water. Environ. Sci. Pollut. R. 21: 5737-46, DOI: 10.1007/s11356-014-2524-5

Kendall C. 1998. Tracing Nitrogen Sources and Cycling in Catchments. In: Kendall C, McDonnell JJ (eds) Elsevier Science, Amsterdam, pp 519-576

Kendall C, Elliott EM, Wankel SD. 2008. Tracing Anthropogenic Inputs of Nitrogen to Ecosystems. In Stable Isotopes in Ecology and Environmental Science (eds) R. Michener and K. Lajtha, doi: 10.1002/9780470691854.ch12

Kendall C, Young MB, Silva SR, Kraus TEC, Peek S, Guerin M. 2015. Tracing nutrient and organic matter sources and biogeochemical processes in the Sacramento River and Northern Delta: proof of concept using stable isotope data. U.S. Geological Survey, Data Release, DOI: 10.5066/F7QJ7FCM

Kroopnick P, Craig H. 1972. Atmospheric oxygen: Isotopic composition and solubility fractionation. Science, 175: 54-55, DOI: 10.1126/science.175.4017.54.

Loo SE, Ryan MC, Zebarth BJ, Kuchta SH, Neilsen D, Mayer B. 2017. Irrigated Crops: A Cautionary Vadose Zone Tale. Journal of Environmental Quality, 46: 528-536, DOI: 10.2134/jeq2016.08.0294

McIlvin MR, Altabet MA. 2005. Chemical Conversion of Nitrate and Nitrite to Nitrous Oxide for Nitrogen and Oxygen Isotopic Analysis in Freshwater and Seawater. Analytical Chemistry 200577 (17), 5589-5595, DOI: $10.1021 / \mathrm{ac} 050528 \mathrm{~s}$

Michalski G, Bhattacharya SK, Mase DF. 2012. Oxygen isotope dynamics of atmospheric nitrate and its precursor molecules. In: Baskaram M (ed) Handbook of environmental isotope geochemistry, Springer, Berlin Heidelberg, pp 613-635

Oelmann Y, Kreutziger Y, Bol R, Wilcke W. 2007. Nitrate leaching in soil: Tracing the $\mathrm{NO}_{3}{ }^{-}$sources with the help of stable N and O isotopes. Soil Biology and Biochemistry, 39(12): 3024-3033, DOI: 10.1016/j.soilbio.2007.05.036.

Pardo LH, Kendall C, Pett-Ridge J, Chang CC. 2004. Evaluating the source of streamwater nitrate using $\delta^{15} \mathrm{~N}$ and $\delta^{18} \mathrm{O}$ in nitrate in two watersheds in New Hampshire, USA. Hydrol. Process., 18: 26992712. DOI: $10.1002 /$ hyp. 5576 
Parker SR, Poulson SR, Gammons CH, DeGrandpre MD. 2005. Biogeochemical Controls on Diel Cycling of Stable Isotopes of Dissolved $\mathrm{O}_{2}$ and Dissolved Inorganic Carbon in the Big Hole River, Montana. Environmental Science and Technology 39(18), pp 7134-7140, DOI: 10.1021/es0505595

Paytan A, Kolodny Y, Neori A, Luz B. 2002. Rapid biologically mediated oxygen isotope exchange between water and phosphate, Global Biogeochem Cy, 16, DOI: 10.1029/2001GB001430

Sigman DM, Casciotti KL, Andreani M, Barford C, Galanter M, Böhlke JK. 2001. A Bacterial Method for the Nitrogen Isotopic Analysis of Nitrate in Seawater and Freshwater. Analytical Chemistry 200173 (17), 4145-4153, DOI: 10.1021/ac010088e

Silva S, Kendall C, Wilkison D, Ziegler A, Chang CC, Avanzino R. 2000. A new method for collection of nitrate from fresh water and the analysis of nitrogen and oxygen isotope ratios. J. Hydrol., 228, 22-36, DOI: 10.1016/S0022-1694(99)00205-X

Snider DM, Spoelstra J, Schiff SL, Venkiteswaran JJ. 2010. Stable oxygen isotope ratios of nitrate produced from nitrification: ${ }^{18} \mathrm{O}$-labelled water incubations of agricultural and temperate forest soils. Environ Sci Technol 44:5358-5364 DOI: 10.1021/es1002567

Spalding RF, Exner ME. 1993. Occurrence of nitrate in groundwater: A review. Journal of Environmental Quality, 22, 392-402, DOI: 10.2134/jeq1993.00472425002200030002x.

Spoelstra J, Schiff SL, Elgood RJ, Semkin RG, Jeffries DS. 2001. Tracing the Sources of Exported Nitrate in the Turkey Lakes Watershed Using ${ }^{15} \mathrm{~N} /{ }^{14} \mathrm{~N}$ and ${ }^{18} \mathrm{O} /{ }^{16} \mathrm{O}$ isotopic ratios. Ecosystems 4: 536544, DOI: $10.1007 / \mathrm{s} 10021-001-0027-\mathrm{y}$

Venkiteswaran JJ, Schiff SL, Ingalls BJ. 2018. Quantifying the Fate of Wastewater Nitrogen Discharged to a Canadian River. EarthArXiv, doi:10.17605/OSF.IO/MQ2GN.

Venkiteswaran JJ, Schiff SL, Taylor WD. 2015. Linking aquatic metabolism, gas exchange, and hypoxia to impacts along the 300-km Grand River, Canada. Freshwat Sci 34:1216-1232, DOI: $10.1086 / 683241$

Vitousek PM, Aber JD, Howarth RW, Likens GE, Matson PA, Schindler DW, Schlesinger WH, Tillman DG. 1997. Human alteration of the global nitrogen cycle: sources and consequences. Ecol Appl 7, 737-750, DOI: 10.1890/1051-0761(1997)007[0737:HAOTGN]2.0.CO;2

Wassenaar LI, Koehler G. 1999. An On-Line Technique for the Determination of the $\delta^{18} \mathrm{O}$ and $\delta^{17} \mathrm{O}$ of Gaseous and Dissolved Oxygen. Anal Chem 71:4965-4968, DOI: 10.1021/ac9903961

Wassenaar LI, Venkiteswaran JJ, Schiff SL, Koehler G. 2010. Aquatic community metabolism response to municipal effluent inputs in rivers quantified using diel $\delta^{18} \mathrm{O}$ values of dissolved oxygen. Can J Fish Aquat Sci 67:1232-1246, DOI: 10.1139/F10-057

Xue D, Botte J, De Baets B, Accoe F, Nestler A, Taylor P, Van Cleemput O, Berglund M, Boeckx P. 2009. Present limitations and future prospects of stable isotope methods for nitrate source identification in surface- and groundwater. Water Res 43:1159-1170, DOI: 10.1016/j.watres.2008.12.048

Yue F-J, Li S-L, Zhonga J, Liu J. 2018. Evaluation of Factors Driving Seasonal Nitrate Variations in Surface and Underground Systems of a Karst Catchment. Vadose Zone J 17:170071, DOI:10.2136/vzj2017.04.0071 